\title{
THE DETERMINANTS OF BANK STABILITY: EVIDENCE FROM SELECTED BALKAN COUNTRIES AND TURKEY
}

\author{
ALIHODZIC Almir¹, EKŞİ İbrahim Halii², DOĞAN Berna ${ }^{3}$ \\ ${ }^{1}$ University of Zenica, Faculty of Economics Zenica, Zenica (BOSNA I HERCEGOVINA) \\ ${ }^{2}$ University of Gaziantep, Faculty of Economics and Administrative Sciences, University Avenue, Gaziantep (TURKEY) \\ ${ }^{3}$ University of Gaziantep, Faculty of Economics and Administrative Sciences, University Avenue, Gaziantep (TURKEY) \\ Emails:almir.dr2@gmail.com,eksihalil@gmail.com,dogan.brn@gmail.com
}

\begin{abstract}
The phenomenon of financial stability has gained importance as monetary and fiscal policies aiming at price stability in the global crises are not sufficient to prevent financial crises. After 2007 global crisis, the importance of bank stability better understood. This paper investigates the determinant of bank stability in selected Balkan countries and Turkey. For this aim, we used to Z-score and NPL as dependent variables. We used bank performance, financial structure and macro variables as independent variables. According to ANOVA test and regression analysis, the strongest correlation between non-performing loans as the dependent variable of the Western and some EU Member countries (Bosnia and Herzegovina, Serbia, Croatia, Slovenia, Montenegro, Macedonia) and Turkey was achieved with the following independent variables: the total non-interest income to total income and foreign bank assets to total bank assets. Observed on the other hand, the weakest link between NPLs as a dependent variable was achieved with the following independent variables: the gross domestic product, the net interest margin ratio, Lerner index and the cost to income. Another dependent variable, i.e., Z-score was recorded the strongest correlation with the following independent variables in the model: the gross domestic product, the Lerner index, the net interest margin and the cost to income. The weakest link was achieved with the following independent variables: the total non-interest income to total income and the foreign bank assets to total assets.
\end{abstract}

Keywords: Financial stability, Lerner index, economic activity, Z-Score

JEL: G2, G17, G21

UDC: $338.23: 336.74 .330 .36$

COBISS.SR-ID: 18172937

\section{Introduction}

Globalization, which gained momentum after the 1990s, caused huge monetary movements on world trade and capital flows to developing countries increased significantly. These movements, which started to be speculative, increased the financial vulnerability of developing countries and caused repeated crises in the world economies again.

The 2007-2008 US sub-financial crisis and its consequences on the general economy have increased interest in investigating bank failures that have become central to political and economic debates [1]. In that perıod, leading famous banks and financial institutions (for example Lehman Brothers) had gone bankrupt or recorded huge losses, posing a high risk in the financial market. Consequently, a lot of instability occured in the financial and banking sectors. Therefore, the stability of the banking sector is a major concern for bank supervision 
and academics, but it also attracts attention at a broader macroeconomic level, as the banking sector plays the most important role in the financial sectors.

While the concept of stability can be briefly defined as stability and stabilization, it is also considered as a success criterion. Banking stability can be defined as the stability of banks, which are interconnected by direct participation in interbank deposit markets and syndicated loans, or indirectly by lending to general sectors and registered transactions. Whatever the definition of banking stability may be, a problem that is not entirely understood in the literature is that factors that influence banking stability in emerging economies when considering the role of financial institutions and institutional qualities [2]. According to some experts, capital resources are insufficient to achieve banking stability in developing countries due to structural weaknesses [3]. Given the complexity of modern financial systems as well as the global trends, financial stability has been associated with multidimensional conditions connected to the well-functioning of financial systems (Lassoued, 2017).

The determinants of banking stability and its impact on the stability of the financial system may vary in different countries. The empirical literature shows that some economic factors, financial structures and institutional factors can influence banking stability. This subject is important especially in emerging countries which do not have improved financial systems. So, we use data for Turkey and selected Balkan countries regarded as emerging countries in our analyses.

Similar changes took place in individual Balkan economies both in the economy and in political systems, which meant that they had to build a market economy from scratch in parallel with the restoration of political and state independence [4]. One of the reasons that we investigate these countries is that these countries have quite a similar modern history and experiences about banking application. An important feature of the Central and Eastern European banking sectors is that banks have relatively small and relatively simple traditional business models compared to the EU. And banking sectors in these countries are characterized by a high share of foreign banks and since the late 1990s foreign banks have been playing the role of host countries [5]. Since this year, banking sector in this region countries serious changes have been like this liberalization of capital flows, which leads to privatization, legal, financial and structural reforms, diversification of banking products and services, and an increase in the credibility, robustness and performance of the banking sector [6]. And, Turkish banking sector has features similar to Balkan countries. Banking sector has been growing since 1980s in Turkey [7] also foreign banks entering to Turkish banking sector has been growing since 1990s foreign bank entering to Turkish banking sector is grow after 1990s [51].

In addition to the size and structure of the financial system, there are large differences between the observed countries and are primarily bank-based. Banking sector assets comprise 80 to 92 percent of financial sector assets in the observed countries. For example, these percentage are \%81 in Turkey, \%91.8 in Serbia, \%86.3 Bosnia, \%86.3 in Macedonia and $\% 86.8$ in Montenegro and banking sectors in the region are important levels [13], [14].

Banking sectors in Balkan economies are underdeveloped due primarily to the legacies of the pre-transition planned economy [52]. The economies of selected countries are among those that suffered the most the global downturn of 2007-2009 and after. The one of effects of global crisis observed on non-performing loans. One of the most important problems of banks developing in the Western Balkans since the late 1990s is the poor quality of bank assets [9], [10].

As last dimension, in selected countries, a relatively high level of concentration of the banking sectors was observed [11], [12]. As a result of these, it is important to analyses financial stability and to improve policy for financial stability in these countries. So, it can be prevented more depth economic problems. 
The purpose of this paper is to investigate the determinants of bank stability from 2006 to 2017. To do this, we analyse the financial structure, banking efficiency and macroeconomic variables of both Turkey and selected Balkan countries. We use two measures of banking stability which are Z-score and non-performing loan (NPL). Our explanatory variables include bank performance variables, financial structure and macroeconomic variable.

Therefore, this study is a temporal and contextual extension in the art of science. The second contribution of this study is to analyse the factors which determine the stability of observed countries. For policy makers and bank management it will be useful to control those factors that can destabilize the banking system. And finally, to general society, to help them to choose the safe and stable banks. The findings of this study will provide useful insights for regulators, practitioners, policy makers and researchers for similary emerging countries.

The rest of the article is organized as follows: Section II consists of a review of the literature and various studies on the stability of banks around the world. In section III, the methodological approach, sample, data collection, and research model are discussed. The empirical results of the study are presented in section IV. Section V consists of a conclusion and recommendations.

\section{Literature Review}

It is obvious that the existing literature differs from the past studies according to their sample data, different methodological approach and objectives. Firstly, we find studies that investigate the factors explaining the stability of conventional banks [15], [16], [5], [17].

While some of studies use only country - level data [2], [18], [19], some others use both bank and country level data [20]. However, there is limited studies about both Islamic and conventional banking stability [21], [1]. Diaconu and Oanea [22] used only countries-level data. İbrahim and Rizvi [23] and Lassoued [24] investigated only bank stability on islamic bank.

One of the controversial aspects in literature pertains to the role of competition in influencing bank stability. Competition is usually considered a positive force in most industries; this is expected to have a positive impact on industry performance, delivery quality, innovation and international competitiveness [25]. Scientists and policymakers have focused on the role of banking competition in the stability of the financial system, as well as bank-specific factors that can influence relationships such as size, capitalization, and liquidity [26].

There are a number of studies that have investigated the effect of bank competition on banking stability. Competitive conditions in the financial sector are also relevant to be studied due to their impact on financial stability [27]. These studies have shown that there is generally no consensus on whether competition in the banking system leads to stability or fragility [26], [27], [28], [29], [17], [20].

The other important dimension of bank stability is bank concentration degree. Karkowska and Pawłowska [5], Shijaku [30], Ijtsma et al., [20] and Kasman and Kasman [31] investigate how the level of concentration affects stability.

In addition to the internal determinants of stability, represented generally by the characteristics of the bank, the macroeconomic environment in which banks operate remains the country's macroeconomic variable and an external factor that can affect the stability of the bank. For example, Adusei [16] investigated the effect of internal factors (bank size, funding risk) on bank stability. Similarly, while Wang et al., [15] investigated the cost and profit efficiency, Lassoued (2017) investigated corporate governance. Apart from these Pak [32] investigated the effect of ownership structure on bank stability. Moreover Ozili [2] 
investigated the determinants of banking stability using bank-level variables; financial structure; institutional quality and macroeconomic factors.

The last dimension of bank stability is institutional development on banking sector such as Fang et al., [18]2014; Hou and Wang, [33].

Our study differs from previous studies. The situation in the banking sector has been studied from different perspectives: its stability, profitability, efficiency, competition, concentration. But, related to stability, there are a few papers in selected countries [34], [35].

And, we can not see paper about bank stability compare Turkey and Balkan countries.

\section{Data and Methodology}

\section{Data}

This empirical study uses country-level data for observed countries. The data is annual for a period of twelve years between 2006 and 2017. We use the balanced panel data, which are obtained from the Bankscope database, the World Bank and from central banks of selected countries. We use two dependent variables called Z-score and NPL as the measure of financial stability. We use six independent variables as foreign banks (FRG), Lerner index (LRN), net interest margin (NIM), non-interest income (NII), bank cost to income (CI), and gross domestic product (GDP).

We would like to answer the following question: Which of the independent variables in the model has the strongest impact on the banking stability of the observed countries on the one hand, and on the other hand, which of the variables has the lowest impact? In this research, we will present a modified version of the model developed by Abel et al., [29] and Ozili [2].

We will present the model in the following way:

$$
\text { Stability }=\mathrm{f} \text { (financial structure, bank efficiency, macroeconomic factors) (1) }
$$

The preceding equation is adapted to the dependent and independent variables in the model:

$$
\begin{aligned}
\text { ZScore } i, t= & \beta 1 N I M i, t+\beta 2 N I I i, t+\beta 3 C I i, t+\beta 4 L R N i, t+\beta 5 F R G i, t \\
& +\beta 6 G D P i, t+e(2)
\end{aligned}
$$

The Z-score is a widely-used bank stability measure [31], [21], [5], [2], [29], [36]. It represents the ratio of bank buffer capital and profit to the risk of volatility in returns. The ZScore indicates how quickly a company's profits would decline before a bank's capitalization is used up.

The Z-Score combines the profitability, capital ratio and return volatility of the banks in a single indicator. Apparently, the Z-Score will increase with banks' profitability and capital ratio and decrease with increasing volatility in returns. From an economic point of view, the Z-Score therefore first measures the likelihood of a bank going bankrupt if the value of the assets falls below the value of the debt. A higher (lower) Z-Score therefore implies a lower (higher) probability of an insolvency risk [19].

For another dependent variable, i.e., for NPL, the regression equation can be expressed as follows:

$$
N P L i, t=\beta 1 N I M i, t+\beta 2 N I I i, t+\beta 3 C I i, t+\beta 4 L R N i, t+\beta 5 F R G i, t+
$$
$\beta 6 G D P i, t+e(3)$ 
We also use NPL, another measure commonly used for stability [31], [2], [29], [37]. This analysis allows us to understand whether competition has an impact on systemic risk measured by the level of non-performing loans. The higher the value of the indicator, the risk is the bank's portfolio. Higher non-performing loans indicate lower credit quality, higher bank sensitivity or levels of lending corruption.

We use common independent variables for two models. We divided the independent variables as financial structure, banking effiiency and macroeconomic. We use foreign ownership on banking sector and Lerner Index for financial structure of banking sector.

Foreign banks can be a channel for spreading shocks in one country and affecting the credit supply in another. As a result, foreign banks can cause financial instability [38].

However, the presence of foreign banks can also bring new technologies, new financial services and products, and can also provide a wide range of financial services to the country's financial service users, thus jointly improving the breadth and depth of financial intermediation in the financial system helps to establish more stable financial system [2].

Foreign ownership in banking sector is especially important for observed countries.

There are a number of studies that have investigated the effect of bank competition on banking stability [39], [40]. In recent years, studies have investigated competition in the banking industry used various models such as Panzar Rosse $\mathrm{H}$ statistic, Lerner Index and Bresnahan-Lau model. Because of the fact that the lerner index of Lerner index has been widely employed in empirical models of banking competition and measures of market power [41], [42], [29], we prefer Lerner İndex.

The Lerner index is the relative markup of prices relative to marginal costs [43], and is used to measure the extent to which banks exercise market power [44]. The Lerner Index measures the fees charged by mark-up banks to customers by calculating the difference between price and marginal cost (expressed as a percentage of price). A higher value of the Lerner index means a lower level of bank competition.

We use three variables to measure bank efficiency. First, bank efficiency is measured by the net interest rate of return (NIM), which refers to a bank's net interest income as a share of its average interest-bearing assets. A higher level of net interest margin may indicate that the banking industry is inefficient, the market power is enhanced or the market competition structure is reduced, so that banks can earn higher profit margins. Profitable banks have higher NIMs and are more stable than less profitable banks [45].

Our second variable is non-interest income. Non-interest-related income includes net income from transactions and derivatives, net income from other securities, net fees and commissions, and other operating income. A related question to ask here is: Will the bank's decision to switch to non-interest income generating activities affect bank risk? Indeed, as documented by Armstrong and Vashishtha (2012), executives have an incentive to reduce idiosyncratic risks while increasing systemic risks. Therefore, some people believe that engaging in non-interest income activities will diversify a bank's investment portfolio, thereby reducing its unique risks [46].

The last variable in the efficiency of the banking sector is the cost-to-income ratio. This is important because the bank's operating expenses account for the sum of net interest income and other operating income [45].

We take gross domestic product (GDP) as the most important indicator of economic growth. During periods of rapid economic growth, loan default rates tend to be low, which has a positive impact on the stability of the banking industry [2].

We show below both dependent and independent variables on Table 1. 
Table 1. brief description of the dependent and independent variables

\begin{tabular}{|l|l|l|}
\hline VARIABLE & MEASURED BY & REFERENCES \\
\hline $\begin{array}{l}\text { Foreign Bank } \\
\text { (FRG) }\end{array}$ & $\begin{array}{l}\text { Foreign bank assets/total bank } \\
\text { assets }\end{array}$ & Ozili [2], Karkowska and Pawłowska [5] \\
\hline \multirow{2}{*}{ Lerner index (LRN) } & $\begin{array}{l}\text { Difference between output prices } \\
\text { and marginal costs }\end{array}$ & Abel et al., [29] \\
\cline { 2 - 3 } & Ozili [2], Chileshe [26], Kasman and Kasman [31] \\
\hline $\begin{array}{l}\text { Net interest margin } \\
\text { (NIM) }\end{array}$ & $\begin{array}{l}\text { net interest income/invested } \\
\text { assets }\end{array}$ & Ozili [2], Korbi and Bougatef [1] \\
\hline $\begin{array}{l}\text { Non-interest } \\
\text { income (NII) }\end{array}$ & Non-interest income/total income & \begin{tabular}{l} 
Chileshe [26], De Jonghe [47], Stiroh and Rumble [48] \\
\cline { 2 - 3 } Nguret al., [50], Ozili [2] Abuzayed et al., [37],
\end{tabular} \\
\hline Cost to income (CI) [49], Dan1şman [34]
\end{tabular}

\section{Hypothesis}

We would like to test below hypothesis:

I. The null hypothesis is why the independent variable does not significantly affect the dependent variable.

II. The substitution hypothesis is why the independent variable does significantly affect the dependent variable.

The representation of the model will examine calculation of the correlation coefficient (r), the coefficient determination $R^{2}$ and adjusted coefficient determination $\left(\bar{R}^{2}\right)$. There is also an analysis of variance (ANOVA), which will test the significance of all variables in the model.

\section{Results}

The significance test will be performed for all variables using a t-test at a significance level of $95 \%$. Before hypothesis are tested, basic statistics values are given in Table 2 and 3.

Table 2. Descriptive statistics of all variables: 2006-2017

\begin{tabular}{|cccccc|}
\hline Variables & Obs & Mean & Std. Dev. & Min & Max \\
\hline ZScore & 47 & 7.015 & 4.893 & -0.241 & 18.208 \\
NPL & 47 & 13.383 & 6.131 & 2.576 & 21.58 \\
NIM & 47 & 3.990 & 0.974 & 1.851 & 5.667 \\
NII & 47 & 35.734 & 12.154 & 25.146 & 74.057 \\
CI & 47 & 60.615 & 10.553 & 43.149 & 94.317 \\
LRN & 47 & 0.2114 & 0.0960 & -0.002 & 0.324 \\
FGN & 47 & 58.875 & 17.369 & 35 & 88 \\
GDP & 47 & $1.35 \mathrm{e}+11$ & $2.85 \mathrm{e}+11$ & $4.10 \mathrm{e}+09$ & $9.40 \mathrm{e}+11$ \\
\end{tabular}

Source: Calculated by the author (STATA 13.0)

The previous table illustrates the obtained data of descriptive statistics of dependent and independent variables in the model of the countries of the Western Balkans and Turkey.

Given that standard deviation represents a measure of risk, the strongest volatility was recorded by the GDP, followed by the foreign bank assets to total bank assets then the total net interest income to total income and the non-performing loans. The GDP is a very important indicator of economic activity and overall financial situation. In the countries of the 
Western Balkans, the GDP had a very volatile trend. For example, in Bosnia and Herzegovina, the annual growth in 2008 was over 5\%, so that in 2009 it would have recorded a negative value of about 3\%. Stabilization has not come about since 2013. Also, other countries of the Western Balkans had the same trend in circulation except for Turkey, where the growth of GDP had a continuous growth trend.

Table 3. Correlation matrix between dependent and independent variables

\begin{tabular}{|c|c|c|c|c|c|c|c|c|}
\hline Variables & 7Scoro & NPI & NIM & NH & $\mathrm{CI}$ & IN & FDC & CDD \\
\hline & & 1NTL & Niñ & 101 & Cl & LKIV & FKG & GDP \\
\hline ZScore & 1.000 & & & & & & & \\
\hline NPL & -0.036 & 1.000 & & & & & & \\
\hline NIM & 0.407 & 0.457 & 1.000 & & & & & \\
\hline NII & 0.034 & 0.273 & 0.257 & 1.000 & & & & \\
\hline CI & 0.314 & 0.441 & 0.672 & 0.728 & 1.000 & & & \\
\hline LRN & 0.158 & -0.577 & -0.215 & -0.241 & -0.431 & 1.000 & & \\
\hline FRG & 0.204 & 0.603 & 0.787 & -0.072 & 0.440 & -0.537 & 1.000 & \\
\hline GDP & -0.294 & -0.133 & -0.534 & 0.287 & -0.181 & 0.383 & -0.792 & 1.000 \\
\hline
\end{tabular}

From the previous table it can be seen that the strongest correlation between Z-Score with other independent variables: the net interest margin (0.41), then the bank cost - to - income ratio (0.314) and foreign bank assets to total assets (0.204). On the other hand, the weakest correlation between the dependent variable (Z-Score) was achieved with the following independent variables: the non-performing loans (-0.04) and GDP (-0.294). In terms of nonperforming loans, the strongest positive relationship was achieved with the following independent variables: the foriegn banks assets to total bank assets (0.603), then net interest margin (0.457), the cost to income ratio (0.441).

In EU countries, the net interest margin ranges from $1 \%$ to $2 \%$, which is a sign of the development process of financial mediation and the efficient placement of bank loans. Thus, foreign banks make a dominant share in the total portfolio of loans, which in turn leads to an increase in toxic loans due to, on the one hand, a bad debtor's ability to pay and on the other hand due to poor selection and moral hazard. In the Western Balkan countries, 4 to 5 foreign banks account for more than $70 \%$ of the total structural participation in the granting of loans, which certainly represents the oligopolistic position on the banks market. The weakest correlation, non-performing loans has made with the following independent variables: LRN ($0.577)$ and GDP (-0.133).

The table below illustrates the interdependence between Z-Score as the dependent variable and the selected independent variables in the model. The obtained coefficient of determination is $32.5 \%$, while the adjusted coefficient of determination is $22.6 \%$, which means that there are $23 \%$ change in the independent variables to the dependent relation. 
Table 4. The basic model of regression analysis: 2006-2017

\begin{tabular}{|c|c|c|c|c|c|c|}
\hline Source & SS & Df & MS & \multirow{2}{*}{\multicolumn{2}{|c|}{ Number of observations }} & 47 \\
\hline Model & 365.89 & 5 & 60.982 & & & 3.29 \\
\hline Residual & 759.79 & 42 & 18.531 & \multicolumn{2}{|l|}{ Prob $>F$} & 0.000 \\
\hline Total & $1.125,68$ & 47 & 79.513 & \multirow{2}{*}{\multicolumn{2}{|c|}{$\begin{array}{l}\text { R-squared } \\
\text { Adj R-squared }\end{array}$}} & 0.325 \\
\hline & & & & & & 0.226 \\
\hline & & & & Root MSE & & 4.305 \\
\hline $\begin{array}{c}\text { ZScore } \\
\text { (dependent) }\end{array}$ & Coef. & Std. Err. & $\mathbf{T}$ & $P>[t]$ & \multicolumn{2}{|c|}{ [95\% Conf. Interval] } \\
\hline NIM & 2.033 & 1.717 & 1.18 & 0.243 & -1.435 & 5.502 \\
\hline NII & -0.209 & 0.106 & -1.96 & 0.050 & -0.425 & 0.006 \\
\hline $\mathrm{CI}$ & 0.338 & 0.151 & 2.23 & 0.031 & 0.032 & 0.645 \\
\hline LRN & 11.914 & 11.513 & 1.03 & 0.307 & -11.337 & 35.166 \\
\hline FGN & -0.098 & 0.1232 & -0.80 & 0.429 & -0.347 & 0.1503 \\
\hline GDP & $1.39 \mathrm{e}-12$ & $5.23 e-12$ & 0.27 & 0.791 & $9.17 e-12$ & $1.20 \mathrm{e}-11$ \\
\hline _cons & -11.05919 & 8.5402 & -1.29 & 0.203 & 28.306 & 6.188 \\
\hline
\end{tabular}

Source: Calculated by the author (STATA 13.0)

The significance test will be performed for all variables using a t-test at a significance level of $95 \%$. The p-value of the selected variables if greater than 0.05 will be considered to have a significant relationship with the dependent variable, i.e., capital adequacy ratio, otherwise the relationship between the dependent and the independent variable will be considered unsinkable. The previous table shows that the highest significance in terms of $\mathrm{p}$ values has independent cost - to - income (0.03) and non interest income (0.05). Therefore, increasing the probability of bankruptcy leads to an increase in the accompanying costs.

As it seen table, while NII variable is negative relationship with Z-score, CI variable is positive relationship with Z-score. Both variables are important as istatistics. The results are compatible with literature (such as Ozili, De Jonghe [47], Stiroh and Rumble [48], Danışman [34].

The previous table shows that there is a positive link between the the Z-score and GDP.

Also, the positive correlation between Z-Score was achieved with the following independent variables: Lerner index (11.914) and net interest margin (2.033).

A number of major foreign banks in the Western Balkan countries are entering risky placements with the sole aim of achieving high net interest margins, which in turn leads to an increase in Z-Score and a weakening of capital. Observed from the other side, the weakest link Z-Score as a dependent variable was recorded with the following independent variables: the non-interest income to total income (-0.21) and foreign banks assets to total bank assets (0.01). Therefore, with the increase in political and financial instability in the Western Balkan countries, a possible gradual withdrawal of deposits could lead to the withdrawal of foreign banks and further expansion of financial instability. In terms of testing the zero and alternative hypotheses through the empirical and the theoretical value of the F test, we came to the next conclusion. The value of the $\mathrm{F}$ test for 5 degrees of freedom in the numeration and 42 in the denomination was 2.44 . The value of the $F$ test is 3.29 , which is more than the theoretical value which rejects the zero hypothesis and confirms the alternative hypothesis. This also confirms the individual influence of independent variables on the dependent variable.

The table shows the correlation between NPLs and independent variables. It is obvious that greater significance has been achieved between NPLs and independent variables compared to Z-Score and independent variables. The coefficient of determination between the NPLs and the independent variables is $72.30 \%$, while the adjusted determination coefficient is $68.30 \%$. 
Table 5. The basic model of regression analysis: 2006-2017

\begin{tabular}{|c|c|c|c|c|c|c|c|}
\hline Source & SS & Df & MS & \multicolumn{3}{|c|}{ Number of observations $\quad 47$} & \\
\hline Model & $1.278,16$ & 5 & 213.03 & \multicolumn{3}{|c|}{$\mathrm{F}(5,42)$} & \\
\hline Residual & 488,59 & 42 & 11.917 & \multicolumn{2}{|l|}{ Prob $>F$} & 0.000 & \\
\hline Total & $1.766,75$ & 47 & 224.947 & \multirow{2}{*}{\multicolumn{2}{|c|}{$\begin{array}{l}\text { R-squared } \\
\text { Adj R-squared }\end{array}$}} & 0.723 & \\
\hline & & & & & & 0.683 & \\
\hline & & & & Root MSE & & 3.452 & \\
\hline $\begin{array}{c}\text { NPLs } \\
\text { (dependent) }\end{array}$ & Coef. & Std. Err. & $\mathbf{t}$ & $\mathbf{P}>[\mathbf{t}]$ & {$[95 \%$} & Conf. In & terval] \\
\hline NIM & -1.127 & 1.377 & -0.82 & 0.418 & -3.908 & & 1.654 \\
\hline NII & 0.200 & 0.085 & 2.35 & 0.024 & 0.027 & & 0.373 \\
\hline CI & -0.094 & 0.121 & -0.78 & 0.441 & -0.340 & & 0.151 \\
\hline LRN & -6.362 & 9.232 & -0.69 & 0.495 & -25.008 & & 12.284 \\
\hline FGN & 0.251 & 0.098 & 2.54 & 0.015 & 0.0518 & & 0.450 \\
\hline GDP & $-5.46 e-12$ & $4.19 \mathrm{e}-12$ & -1.30 & 0.200 & $-1.39 \mathrm{e}-11$ & & $3.01 \mathrm{e}-12$ \\
\hline _cons & 3.728 & 6.848 & 0.54 & 0.589 & -10.103 & & 17.559 \\
\hline
\end{tabular}

Source: Calculated by the author (STATA 13.0)

Independent variables in the model that had positive values, or a significant effect on the dependent variable is as follows: non-interest income (0.200) and foreign bank assets to total bank assets (0.251). The results are compatible with literature (such as Chileshe, 2017; Nisar et al., [50]. From Table 5 it can be seen that the highest significance in terms of p- and t-test is expressed in the following independent variables: foreign bank asset to total assets $(0.015)$ and non interest income (0.024). Thus, with the increase in the participation of foreign banks in the countries of the Western Balkans and Turkey, has created an oligopolistic position where banks aim at increasing the net interest margin at a higher risk, and due to negative selection and moral hazard, they create toxic credits and increases in the provision and costs.

\section{Conclusion}

We analyzed the determinants of the banking sector in the Western Balkan countries and Turkey from 2006 to 2017. To do this, we use ANOVA tests and regression models. Based on the results, the null hypothesis was rejected because it did not indicate that the independent variable affected the dependent variable. Another hypothesis is acceptable, as the significant impact of selected independent variables on nonperforming loans and Z-score has been shown.

The results of the survey showed that financial stability was tested through the interdependence of NPLs and Z-Score conditioned by macroeconomic indicators, selected indicators of bank operations and certain indicators of the industrial branch. Therefore, the banking stability in the observed countries is primarily determined by specific bank performance, as well as the industry-specific and certain macroeconomic indicators. The strongest correlation between NPLs as dependent variables was recorded with the following independent variables: foreign bank assets to total bank assets and non-interest income.

The weakest link between NPLs as a dependent variable was recorded with the following independent variables: the GDP, the net interest margin and the Lerner index. With the increase of non-performing loans and risk placement, there is a gradual narrowing of net interest margins.

The significant correlation between Z-score as dependent variables was recorded with the following independent variables: non-interest income and bank cost to income. The insignificant link between Z-score as a dependent variable was recorded with the following 
independent variables: the GDP, foreign bank assets to total bank income, the net interest margin and the Lerner index.

These findings offer some important policy implications for regulatory authorities. It is important decrease of NPL and Z-score for bank stabilty. For this aim, both authorities and policy makers need to be monitored closely foreing banking asset, cost to income and noninterest income.

New research by the authors on the given subject can certainly be expanded depending on the availability of the database and the longer time series. Thus, the use of appropriate variables could provide the basis for a better analysis. In addition, the influence of different macroeconomic and regulatory variables on bank stability could be explored. We use only one variables (GDP) as macro economic. It is possible to use different variables. These macroeconomic and regulatory variables could include measures such as the exchange rate, the different corporate governance measures, bank private sector credit to GDP ratio and capital requirements.

\section{REFERENCES}

[1] Korbi F., Bougatef K. (2017) Regulatory Capital and Stability of Islamic and Conventional Banks, International Journal of Islamic and Middle Eastern Finance and Management, Vol. 10(3), pp. 312-330.

[2] Ozili Peterson K. (2018) Banking stability determinants in Africa, International Journal of Managerial Finance, Vol. 14(4), pp. 462-483.

[3] Barth James R., Caprio G., Levine R. (2004), Bank Regulation and Supervision: What Works Best? Journal of Financial Intermediation Vol. 13(2), pp. 205-248.

[4] Kubiszewska K. (2016), The Assessment of the Situation in Banking Sectors in Selected European Countries, Ekonomia i Prawo, Uniwersytet Mikolaja Kopernika, vol. 15(2), pp. 193-208, June.

[5] Karkowska R., Pawłowska M. (2017) The Concentration and Bank Stability in Central and Eastern European Countries, NBP Working Paper No. 272.

[6] Onofrei M., Bostan I., Roman A., Firtescu B. (2018) The Determinants of Commercial Bank Profi tability In CEE Countries, Romanian Statistical Review, Vol. 2, pp. 33-46.

[7] Sümer G. (2016) Türk Bankacılık Sektörünün Tarihsel Gelişimi ve Ab Bankacılık Sektörü İle Karşılaştırılması, Gazi Üniversitesi İktisadi ve İdari Bilimler Fakültesi Dergisi 18/2, pp. 485-508.

[8] Ganić M (2012) The Impact of the Global Financial Crisis on the Banking Sector of Western Balkans: Cross-country Comparison Analysis, Journal of Economic and Social Studies, 2(2), pp. 177-196.

[9] Yüksel S. (2016) Bankaların Takipteki Krediler Oranını Belirleyen Faktörler: Türkiye İçin Bir Model Önerisi, Bankacilar Dergisi, 98, pp. 41-56.

[10] Kubiszewska K. (2015) Banking Concentration in the Baltic and Western Balkan States - Selected İssues, Institute of Economic Research Working Papers No. 68/2015.

[11] The Banks Association of Turkey (2017) https://www.tbb.org.tr/Content/Upload/Dokuman/7519/Bankalarimiz_2017.pdf

[12] The Banks Association of Turkey (2015) https://www.tbb.org.tr/Content/Upload/Dokuman/6257/Bankalarimiz2014.pdf

[13] World Bank Group. (2016), Financial Systems in Western Balkans: Present and Future. World Bank, Washington, DC.

[14] Wang X., Zeng X., Zhang Z. (2014) The İnfluence of the Market Power of Chinese Commercial Banks on Efficiency and Stability, China Finance Review International Vol. 4(4), pp. 307-325.

[15] Adusei M. (2015) The Impact of Bank Size and Funding Risk on Bank Stability, Cogent Economics \& Finance, 3(1), pp. 1-19.

[16] Gómez F., Ponce J. (2010) Loan Market Competition Screening and Bank Stability, Banco Central del Uruguay.

[17] Fang Y., Hasan I., Marton K. (2014) Institutional Development and Bank Stability: Evidence from Transition Countries, Journal of Banking \& Finance 36, pp. 160-176.

[18] Creel J., Hubert P., Labondance F. (2014) Financial stability and economic performance.

[19] Ijtsma P., Spierdijk L. and Shaffer S. (2017) The Concentration - Stability Controversy in Banking: New Evidence from the EU-25, Jounal Of Financial Stability Vol. 33, pp. 273-284.

[20] Trad N., Rachdi H., Hakimi A., Guesmi K. (2017) Banking Stability in the MENA Region During the Global financial Crisis and the European Sovereign Debt, The Journal of Risk Finance Vol. 18(4), pp. 381-397. 
[21] Diaconu I.R., Oanea D.C. (2015) Determinants of bank's stability. Evidence from CreditCoop, Procedia Economics and Finance 32, pp. 488-495.

[22] İbrahim M., Rizvi S. A. (2017) Do We Need Bigger İslamic Banks? An Assessment of Bank Stability, Journal of Multinational Financial Management Vol. 40, pp. 77-91.

[23] Lassoued M. (2017) Corporate Governance and Financial Stability in Islamic Banking, Managerial Finance Vol. 44(5), pp. 524-539.

[24] Casu B. C., Girardone C. (2009) Competition Issues in European Banking, Journal of Financial Regulation and Compliance Vol. 17(2), pp. 119-133.

[25] Chileshe P. M. (2017) Bank Competition And financial System Stability in a Developing Economy: Does Bank Capitalization and Size Matter? Bank of Zambia BoZ Working Paper 5/2017.

[26] Louati S., Boujelbene Y. (2015) Banks' Stability-Efficiency within Dual Banking System: A Stochastic Frontier Analysis, International Journal of Islamic and Middle Eastern Finance and Management, Vol. 8(4), pp. 472-490.

[27] Goetz M. (2016) Competition and Bank Stability, CFS Working Paper Series, No. 559.

[28] Abel S., Roux P. L., Mutandwa L. (2018) Competition and Bank Stability, International Journal of Economics and Financial Issues, 8(3), pp. 86-94.

[29] Shijaku G. (2017) Does Concentration Matter for Bank Stability? Evidence from the Albanian Banking Sector, Journal of Central Banking Theory and Practice, 3, pp. 67-94.

[30] Kasman S., Kasman A. (2015) Bank Competition, Concentration and Financial Stability in The Turkish Banking Industry, Economic Systems Vol. 39, pp. 502-517.

[31] Pak O. (2018) The Impact of State Ownership and Business Models on Bank Stability: Empirical Evidence from the Eurasian Economic Union, The Quarterly Review of Economics and Finance.

[32] Hou X., Wang Q. (2016) Institutional Quality, Banking Marketization and Bank Stability: Evidence from China, Economic Systems Vol. 40(4), pp. 539-551.

[33] Danışman Gamze Ö. (2018) Determinants of Bank Stability: A Financial Statement Analysis of Turkish Banks, Sosyoekonomi, Vol. 26(38), pp. 87-103.

[34] Koç Yasemin Deniz and Karahan Ferit (2017) Financial Stability Indıcators of Turkish Banking Sector, International Journal of Academic Value Studies, pp. 3-15, pp. 148-153.

[35] Ali M., Puah C.H. (2018) The Internal Determinants of Bank Profitability and Stability: An Insight from Banking Sector of Pakistan, Management Research Review.

[36] Abuzayed B., Al-Fayoumi N., Molyneux P. (2018) Diversification and Bank Stability in the GCC. Journal of International Financial Markets, Institutions and Money.

[37] Claessens S., Van Horen N. (2013) Impact of Foreign Banks. Journal of Financial Perspectives, Vol. $1(1)$.

[38] Staikouras C., Wood Geoffrey E. (2000) Competition and Banking Stability in the Euro Area: The Cases of Greece and Spain. The Journal of International Banking Regulation, 2, pp. 7-24.

[39] Liu Hong, Molyneux Phil and Wilson John O.S. (2013) Competition and Stability in European Banking: A Regional Analysis, The Manchester School Vol. 81(2), pp. 176-201.

[40] Simpasa Anthony M. (2013a) Increased Foreign Bank Presence, Privatisation and Competition in the Zambian Banking Sector, Managerial Finance Vol. 39(8), pp. 787-808.

[41] Arrawatia, R., Misra A., Dawar V. (2014) Bank Competition and Efficiency: Empirical Evidence from Indian Market, International Journal of Lawand Management Vol. 57(3), pp. 217-231.

[42] Lerner, A.P. (1934) The Concept of Monopoly and the Measurement of Monopoly Power. The Review of Economic Studies, 1, pp. 157-175.

[43] Simpasa Anthony Musonda (2013b) Competition and Market Structure in the Zambian Banking Sector, African Development Bank Group, Working Paper series No. 168.

[44] Dwumfour Richard Adjei (2017), Explaining Banking Stability in Sub-Saharan Africa, Research in International Business and Finance, Vol. 41, 260-279.

[45] Chen Carl R., Huang Ying Sophie and Zhang Ting (2017) Non-Interest Income, Trading, and Bank Risk, Journal of Financial Services Research, 51, pp. 19-53.

[46] De Jonghe O. (2010) Back to the Basics in Banking? A Micro-Analysis of Banking System Stability. Journal of Financial Intermediation, 19(3), pp. 387-417.

[47] Stiroh K. J., Rumble A. (2006) The Dark Side of Diversification: The Case of US financial Holding Companies. Journal of Banking and Finance 30(8) pp. 2131-2161.

[48] Nguyen My, Skully Michael, Perera Shrimal (2012) Market Power, Revenue Diversification and Bank Stability: Evidence from Selected South Asian Countries, Journal of International Financial Markets, Institutions and Money, Elsevier, vol. 22(4), pp. 897-912.

[49] Nisar S., Peng Ke, Wang Susheng and Ashraf Badar Nadeem (2018) The Impact of Revenue Diversification on Bank Profitability and Stability: Empirical Evidence from South Asian Countries, International Journal of Financial Studies, 6(2), 40, pp. 1-25. 
[50] TBB, Bankacılık ve Araştırma Grubu. Türkiye'de Yabancı Bankalar; Bankacılar Dergisi, Sayı 52, 2005.

[51] Bonin John P. (2001), Financial Intermediation in Southeast Europe: Banking on the Balkans, the wiiw Balkan Observatory, Working Papers, No. 006.

\section{Article history:}

Received 26 February 2020

Accepted 28 Juny 2020 